\title{
ГІДРОБІОЛОГІЯ
}

УДК 504.453.054(477.84)

doi: 10.25128/2078-2357.19.2.10

${ }^{1}$ Г. Б. ГУМЕНЮК, ${ }^{1}$ О. С. ВОЛОШИН, ${ }^{1}$ В. О. ХОМЕНЧУК, ${ }^{2}$ Н. Г. ЗІНЬКОВСЬКА

${ }^{1}$ Тернопільський національний педагогічний університет імені Володимира Гнатюка вул. М. Кривоноса, 2, Тернопіль, 46027

${ }^{2}$ Кременецька обласна гуманітарно-педагогічна академія імені Тараса Шевченка пров. Ліцейний, 1, Кременець, 47003

e-mail: gumenjuk@chem-bio.com.ua

\section{ДИНАМІКА ВМІСТУ НІТРОГЕНОВМІСНИХ СПОЛУК У ГІДРОЕКОСИСТЕМАХ РІЧОК ПРИП'ЯТЬ ТА ТУРІЯ}

Досліджено вміст нітрогеновмісних сполук у воді річок Прип'ять та Турія Волинської області в різні сезони року. Здійснена екологічна оцінка якості води р. Турія та р. Прип’ять.

Ключові слова: аміак, нітрати, водойми, токсичність, якість води, категорія.

Сьогодні більшість річок України загалом та Волинської області зокрема, у тому числі й p. Турія та р. Прип'ять, є забрудненими унаслідок недостатності природоохоронних заходів в умовах антропогенного тиску, що спричинений забрудненням води промисловими, комунальними стічними водами, заростанням русла, цвітінням води тощо.

В останні роки, зокрема у 2012 р., 2015 р., 2016 p., у засобах масової інформації обговорювались питання щодо погіршення екологічного стану основної водної артерії Ковельського району р. Турії та щодо виявлення джерел іiі забруднення. На сьогоднішній день найгострішою проблемою p. Турії $€$ повсюдне порушення і недотримання водоохоронного режиму в населених пунктах іiі басейну, зокрема в м. Ковель. Так, серед містян Ковеля поширеною практикою стало забруднення водойм стоками від приватних домогосподарств. Ще однією причиною погіршення гідрологічного та екологічного стану річки у 2015-2016 pp. $є$ вплив кліматичних чинників: високі температури повітря влітку та дефіцит опадів, що сформували низьку (за рівнями та витратами води) літню межень, яка спричинила обміління, щільне заростання очеретом русла, формування ділянок стоячої води та цвітіння води. Треба також відзначити, що упродовж кількох років поспіль у р. Турія фіксувались факти масової загибелі риби улітку. Тому екологічна оцінка якості води на сьогодні $є$ актуальна і важлива для природоохоронних заходів в басейні Дніпра [12]. Природними компонентами та водночас забрудниками водних систем $\epsilon$ нітрогеновмісні сполуки, при перевищенні природних концентрацій яких втрачається баланс між фізіологічним та токсичним впливом [9]. Сполуки Нітрогену (амоній, нітрати) утворюються у воді в результаті біохімічного розкладання і окислення органічних залишків природного походження, а також потрапляють у річки та водойми зі стічними водами. Високі концентрації Нітрогену амонійного найчастіше характерні для болотних вод і можуть свідчити про свіже фекальне забруднення водного об'єкта. Підвищені концентрації нітратів у воді $\epsilon$ наслідком забруднення водойми промисловопобутовими стічними водами і стоками з сільськогосподарських полів. Неорганічні сполуки Нітрогену за високого їх вмісту у воді можуть викликати отруєння гідробіонтів, причому найменшою токсичністю характеризуються нітрати. Вони є кінцевим продуктом мінералізації 
органічних речовин і їх наявність у воді вказує на закінчення цього процесу та свідчить про давність забруднення води органічними речовинами [2].

\section{Матеріал і методи досліджень}

Об'єктами досліджень була міграція нітрогеновмісних сполук в екосистемах річок Прип'ять і Турія Волинської області. Відбір проб води проводили з поверхневого горизонту водойм по середині річки на глибині 0,5-0,7 м за допомогою пластикових пробовідбірників об'ємом 1 дм $^{3}$. Для дослідження вмісту у воді нітрогеновмісних сполук зразки відбирали в 5-ти різних місцях річки Турія (рис. 1)

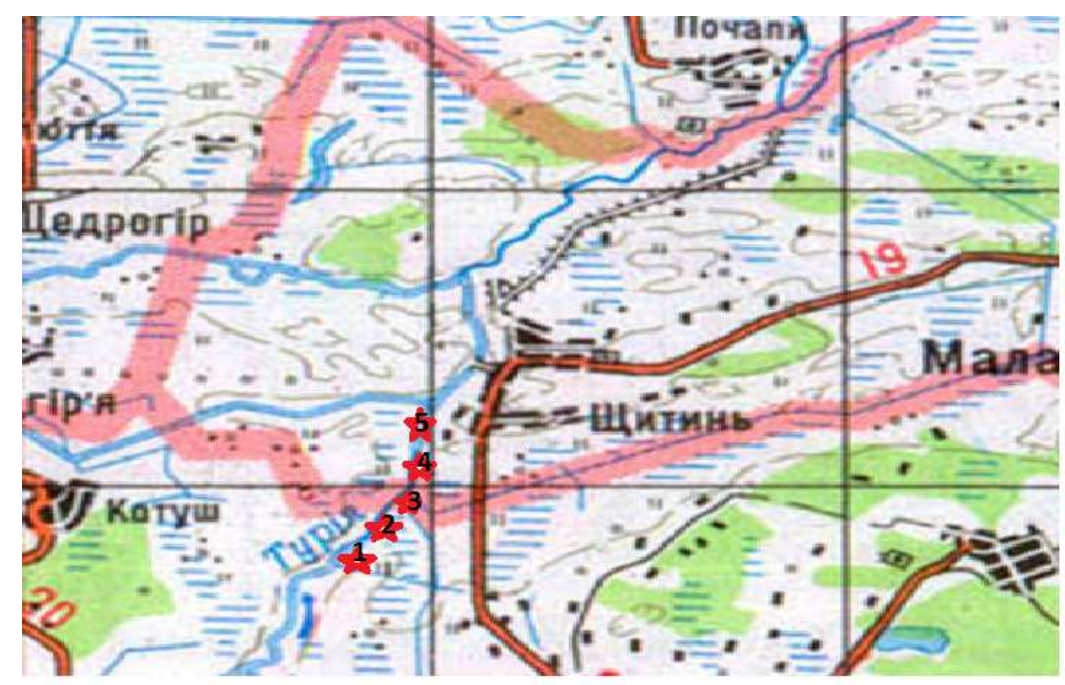

Рис. 1. Картосхема досліджуваної території р. Турії: 1 - початок села Щитинь; 2 біля будівель; 3 - біля пляжу; 4 - біля водопою; 5 - місце впадіння р. Турії в р. Прип'ять (Масштаб 1:100000).

Для дослідження вмісту у воді нітрогеновмісних сполук зразки відбирали в 5-ти різних місцях річки Прип’ять (рис. 2).

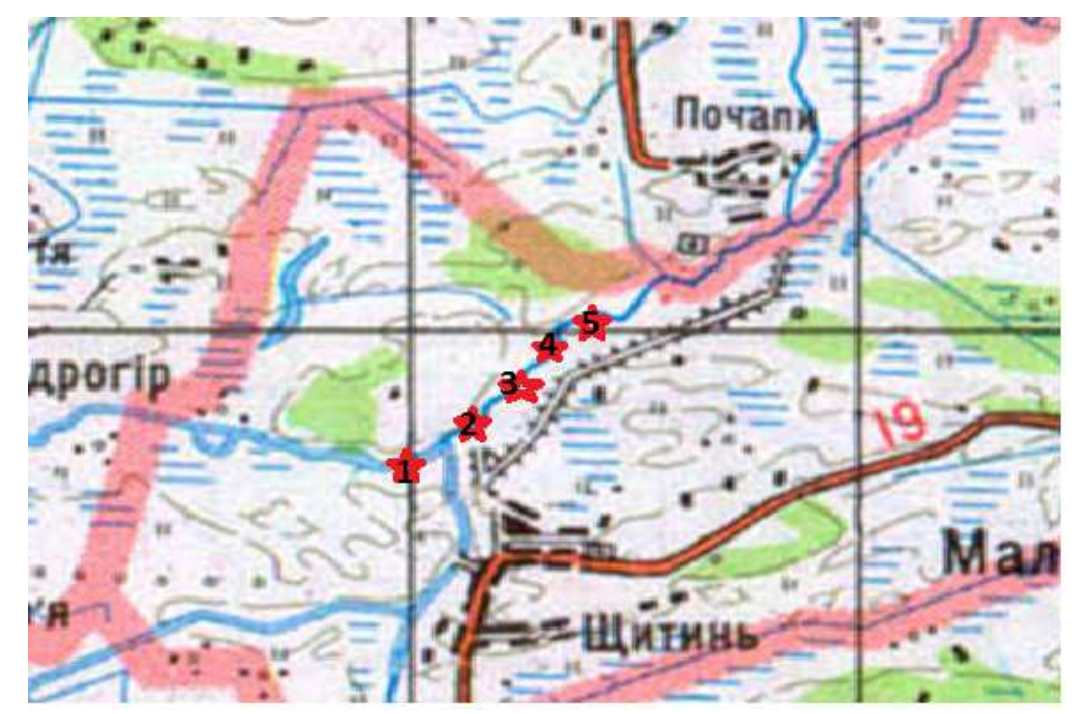

Рис. 2. Картосхема досліджуваної території р. Прип’яті: 1 - початок р. Прип’ять; 2 - біля пляжу; 3 - біля водопою; 4 - біля будівель; 5 - кінець села Щитинь (Масштаб 1:100000). 
Вміст нітратів у воді річок досліджуваних територій визначали колориметрично 3 фенолдисульфокислотою з утворенням нітровмісного фенолу жовтого кольору [8] при довжині хвилі 520 нм. Вміст амонію визначали фотометричним методом за якісною реакцією 3 реактивом Несслера $[8,11]$ при довжині хвилі 420 нм.

Статистичне опрацювання даних здійснювали за допомогою пакету прикладних програм Statistica 5.5 i Microsoft Office Excel 2010.

\section{Результати досліджень та їх обговорення}

Сполуки Нітрогену істотно погіршують органолептичні властивості води $[1,4]$. У поверхневих водах вони знаходяться у розчиненому, колоїдному та зваженому стані і під впливом багатьох фізико-хімічних та біохімічних чинників переходять з одного стану в інший.

Середня концентрація загального Нітрогену в природних водах коливається в значних межах і залежить від трофності водного об'єкта: для оліготрофних змінюється звичайно в межах 0,3-0,7 мг/дм³ , для мезотрофних - 0,7-1,3 мг/дм ${ }^{3}$, для евтрофних - 0,8-2,0 мг/дм³.

Нітроген амонійний - один з найважливіших біогенних елементів рослинних, тваринних організмів та мікроорганізмів, який відіграє важливу роль у функціонуванні водних екосистем [10].

У річці Прип'ять мінімальні значення вмісту $\mathrm{NH}_{4}{ }^{+}$впродовж дослідження спостерігали у травні (0,024 мг/л), максимальні - у червні (0,1766 мг/л) (рис. 3).

У річці Турія мінімальне значення вмісту нітрогену амонійного спостерігали у червні (0,025 мг/л), максимальне - у серпні (2,991 мг/л). Слід зазначити, що зміни концентрації $\mathrm{NH}_{4}{ }^{+}$у воді, зокрема при забрудненні водойм промисловими стічними водами чи агростоками, не відбуваються безслідно для екосистеми: зменшення може бути причиною погіршення життєдіяльності аеробних мікроорганізмів, рослинних організмів товщі води, а збільшення, особливо в поєднанні з підвищенням вмісту фосфатів, веде до сплеску розвитку синьо-зелених водоростей зі зсувом рівноваги у водній екосистемі в бік процесів евтрифікації $[11,13]$.

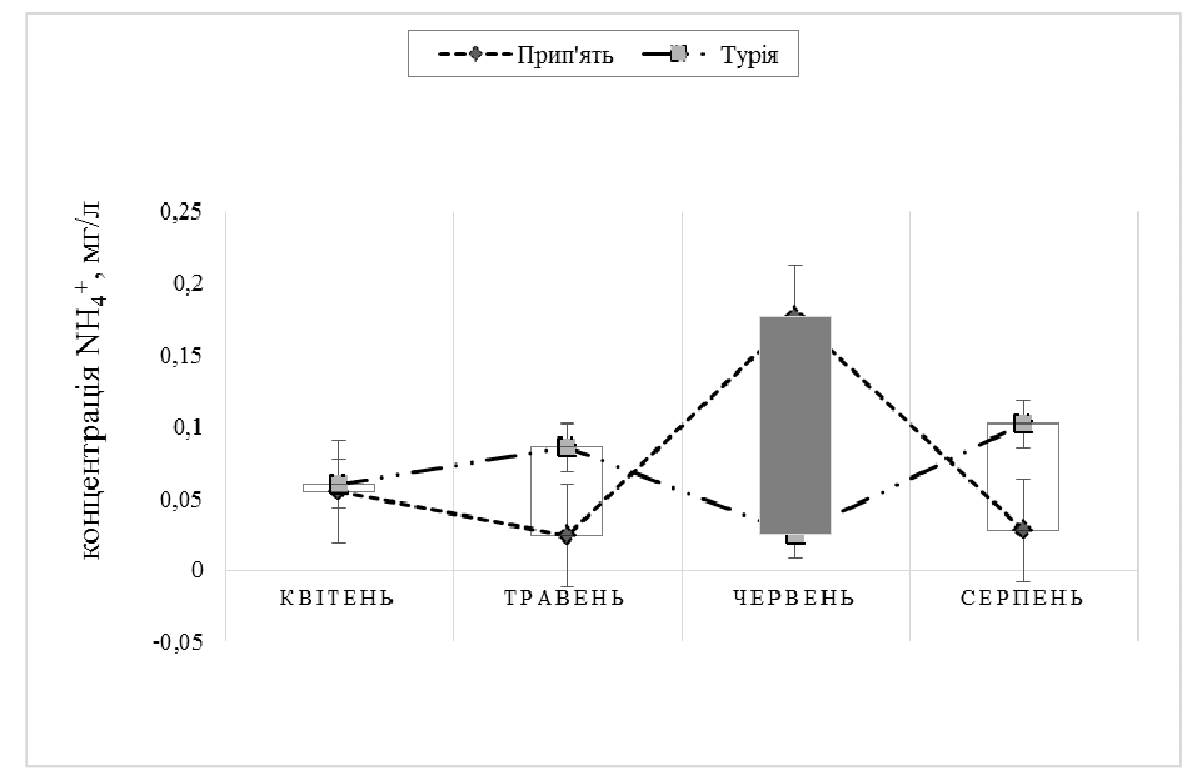

Рис. 3. Вміст йону амонію у воді річок Волинської області впродовж квітня-серпня 2018 p. $(\mathrm{M} \pm \mathrm{m} ; \mathrm{n}=5)$

Присутність нітратів у поверхневих водах пов' язана із процесами нітрифікації амонійних йонів в присутності кисню, атмосферними опадами, стічними водами та змивом iз сільськогосподарських угідь.

Як відомо, основні процеси, що призводять до зниження концентрації нітратів - потреби фітопланктону та денітрифікуючі бактерії, котрі за дефіциту $\mathrm{O}_{2}$ використовують кисень нітратів для окислення органічних речовин [3]. 
Нітрати є кінцевим продуктом мінералізації органічних речовин. Наявність їх у воді вказує на закінчення цього процесу та свідчить про давність забруднення води органічними речовинами [5]. У поверхневих водах нітрати знаходяться в розчиненій формі [6].

Концентрація нітратів у поверхневих водах схильна до сезонних коливань: мінімальна у вегетаційний період, збільшується восени і досягає максимуму взимку, коли при мінімальному споживанні нітрогену відбувається розкладання органічних речовин і перехід нітрогену 3 органічних форм у мінеральні [7].

Кількість нітратів у поверхневих водах, як правило, невелика. Головним джерелом їх надходження $\epsilon$ грунтовий шар, у якому нітрати накопичуються як внаслідок природних процесів, так і внаслідок внесення азотних добрив.

Мінімальні значення вмісту нітратів досліджуваних водних об'єктів спостерігали у травні (р. Турія - 0,552 мг/л, р. Прип'ять - 0,604 мг/л) (початок вегетаційного сезону), максимальні - у квітні (р. Турія - 1,486 мг/л, р. Прип'ять 1,580 мг/л). Також невисокі концентрації нітратів спостерігались у серпні (р. Турія - 0,664 мг/л, р. Прип’ять - 0,634 мг/л) (друга фаза вегетаціï) (рис. 4)

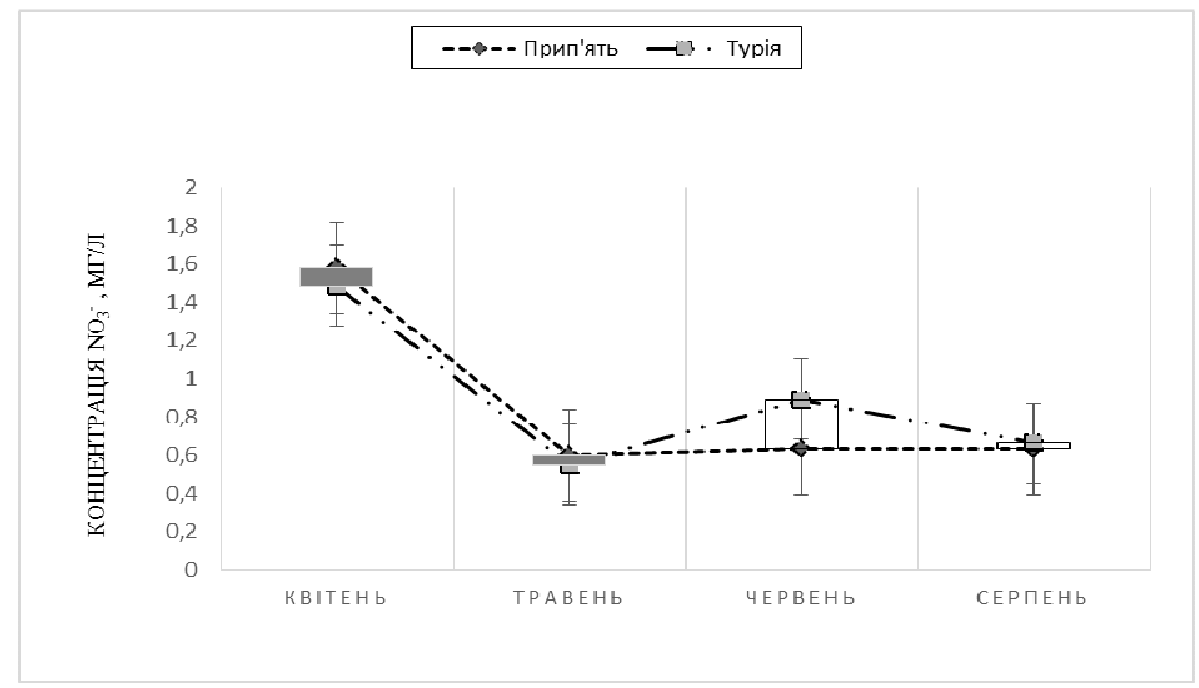

Рис. 4. Вміст нітратів у воді річок Волинської області впродовж квітня-серпня 2018 p. $(\mathrm{M} \pm \mathrm{m} ; \mathrm{n}=5)$

Отже, у річках Прип'ять та Турія вміст нітратів збільшується навесні, що, очевидно, пов'язано 3 паводковими водами 3 водозборів. У літній період концентрація нітратів залишається невисокою внаслідок активної їх асиміляції водною рослинністю.

\section{Висновки}

Сезонна динаміка вмісту нітрогеновмісних сполук у воді річок Прип'ять та Турія Волинської області має коливальний характер. Зростання вмісту амонійного Нітрогену, ймовірно, пов’язано із зниженням концентрації кисню внаслідок евтрофікації водойми.

Згідно екологічної класифікації якості поверхневих вод України за трофосапробіологічними (еколого-санітарними) критеріями по вмісту Нітрогену амонійного річки Турія та Прип'ять належать до II категорії (добрі, мезоевтрофні) по вмісту нітратів до III категорії (евтрофні, задовільні).

1. Бескровная М. В. Оптимизация процесса биологического удаления минерального азота из сточных вод. Вода і водоочисні технології. 2008. № 3 (27). С. 44-48.

2. Бессонов Н. М. Привезенцев Ю. А. Рыбохозяйственная гидрохимия. М.: Агропромиздат, 1987. 159 с.

3. Бияк В. Я., Ляврін Б. З., Хоменчук В. О., Курант В. З. Аналіз гідрохімічних показників малих річок Західного поділля. Наукові записки ТНПУ ім. Володимира Гнатюка. Серія: Біологія. 2010. № 4 (45). C. $115-121$. 
4. Клоченко П. Д. Динамика неорганических соединений азота в загрязненных малых реках в связи с развитием фитопланктона (на примере некоторых притоков Днепра). Гидробиологичный журнал, 1995. № 1. T. 31. С. 95-102.

5. Коткова Т. М., Котков В. І., Селезньова Г. О. Моніторинг забруднення сполуками азоту річок Лугинського району Житомирської області. Вісник Житомирського національного агроекологічного університету. 2011. № 2 (29), Т. 1. С. 106-112.

6. Маджд С. М., Франчук Г. М., Тимошенко М. М. Екологічна оцінка якості поверхневих і грунтових вод у районі ремонту та експлуатації авіаційної техніки. Екологічна безпека та природокористування: збірник наукових праць. К., 2012. Вип. 9. С. 116-122.

7. Маджд С. М., Кіпніс Л. С., Франчук Г. М. Перспективи розробки методів біотестування для контролю впливу на довкілля авіатранспортних процесів. Наука та молодь. К.: НАУ, 2003. С. 125-129.

8. Новиков Ю. В., Ласточкина К. О., Болдина 3. Н. Методы исследования качества воды водоемов. М.: Медицина, 1990. - 400 с.

9. Романенко В. Д. Основи гідроекології. К.: Обереги, 2001. 728 с.

10. Федоненко О. В., Слабоспицька О. В. Сезонна динаміка трофо-сапробіологічних показників води середньої частини Запорізького (Дніпровського) водосховища. Проблеми екології та охорони природи техногенного регіону. 2011. № 1 (11). С. 111-121.

11. Чибисова Н. В. Практикум по экологической химии. Калининград: Калининградский университет , 1999. - 94 c.

12. Характеристика річки Прип'ять (Електронний ресурс) / Режим доступу: https://knowledge.allbest.ru/geology/2c0a65625b2ac68a4d53a89521316c26_0.html.

13. Galloway J., Dentener F., Capone D., Galloway J. Nitrogen cycles: past, present and future. Biogeochemistry. 2004. V. 70 (2). P. 153-226

\section{References}

1. Beskrovnaia M.V. Optimizatsiia protsessa biologicheskogo udaleniia mineral'nogo azota iz stochnykh vod. Voda i vodoochysni tekhnolohii. 2008. No3 (27). S. 44-48.

2. Bessonov N.M. Privezentsev Iu.A., Rybokhoziaystvennaia gidrokhimiia. M. Agropromizdat, 1987. - 159 s.

3. Byiak V.Ya. Liavrin B.Z., Khomenchuk V.O., Kurant V.Z. V.Z. Analiz hidrokhimichnykh pokaznykiv malykh richok Zakhidnoho podillia. Naukovi zapysky TNPU im. Volodymyra Hnatiuka. Seriia: Biolohiia. 2010. No 4 (45). S. 115-121.

4. Klochenko P.D. Dinamika neorganicheskikh soedineniy azota v zagriaznennykh malykh rekakh v sviazi s razvitiem fitoplanktona (na primere nekotorykh pritokov Dnepra). Gidrobiologichnyy. zhurnal.1995. No1., T.31. S. 95-102.

5. Kotkova T.M., Kotkov V.I., Selezn'ova H.O. Monitorynh zabrudnennia spolukamy azotu richok Luhyns'koho rayonu Zhytomyrs'koi oblasti. Visnyk Zhytomyrs'koho natsional'noho ahroekolohichnoho universytetu. 2011. No 2 (29), T.1. S.106-112

6. Madzhd S.M., Franchuk H.M., Tymoshenko M.M. Ekolohichna otsinka iakosti poverkhnevykh i gruntovykh vod $\mathrm{u}$ rayoni remontu ta ekspluatatsii aviatsiynoi tekhniky. Ekolohichna bezpeka ta pryrodokorystuvannia: Zbirnyk naukovykh prats'. K., 2012. Vyp.9. S.116-122.

7. Madzhd S.M.. Kipnis L.S, Franchuk H.M. Perspektyvy rozrobky metodiv biotestuvannia dlia kontroliu vplyvu na dovkillia aviatransportnykh protsesiv. Nauka ta molod'. K.: NAU, 2003. S. 125-129.

8. Novikov Iu.V., Lastochkina K.O., Boldina Z.N. Metody issledovaniia kachestva vody vodoemov. M.: Meditsina, 1990. - $400 \mathrm{~s}$.

9. Romanenko V.D. Osnovy hidroekolohii: K.: Oberehy, 2001. 728 s.

10. Fedonenko O. V., Slabospyts'ka O. V. Cezonna dynamika trofo-saprobiolohichnykh pokaznykiv vody seredn'oi chastyny Zaporiz'koho (Dniprovs'koho) vodoskhovyshcha. Problemy ekolohii ta okhorony pryrody tekhnohennoho rehionu. 2011. No 1 (11). S.111-121.

11. Chibisova N.V. Praktikum po ekologicheskoy khimii. Kaliningrad: Kaliningradskij universitet, 1999. - 94 s.

12. Kharakterystyka richky Pryp'iat' (Elektronnyy resurs) / Rezhym dostupu: https://knowledge.allbest.ru/geology/2c0a65625b2ac68a4d53a89521316c26_0.html

13. Galloway J., Dentener F., Capone D., Galloway J. Nitrogen cycles: past, present and future. Biogeochemistry. 2004. V. 70(2). P. 153-226 
H. B. Humeniuk, O. S. Voloshun, V. O. Khomenchuk, N. G. Zinkovska

Ternopil Volodymyr Hnatiuk National Pedagogical University, Ukraine

Taras Shevchenko Regional Humanitarian-Pedagogical Academy of Kremenets, Ukraine

THE DYNAMIC OF THE CONTENT OF NITROGEN CONTAINING COMPOUNDS IN THE HYDROEKOSYSTEMS OF THE PRIPIAT RIVER AND THE TURIA RIVER

Nowadays, most of the rivers of Ukraine in general and the Volyn region in particular are contaminated with ordinary human negligence, as environmental measures are not sufficiently implemented. The Turia and the Pripiat River are also an exception. In recent years, they have undergone considerable anthropogenic pressure, which caused water pollution with industrial, municipal wastewater, deterioration of water quality, overgrowth of the bed, flowering of water, etc. In this regard, the assessment of water quality is extremely important.

Inorganic nitrogen compounds (ammonium and nitrates) are characterized by high biological activity. They determine the trophic state and productivity of reservoirs.

It should be noted that an increase in the concentration of nitrogen-containing compounds leads to a burst of development of blue-green algae with a shift of equilibrium in the aquatic ecosystem towards eutrophication process.

The concentrations and the peculiarities of the spring and summer redistribution of inorganic nitrogen compounds in the water of the Pripiat and Turia Rivers are investigated. An indicative tropho-saprobiological evaluation of the status of the hydro-ecosystems was conducted.

The results obtained provide a theoretical and scientific basis for establishing the regulatory factors that determine the content of Nitrogen (ammonium and nitrate) compounds in the water of the Pripiat and Turia rivers. The identified features can be used in the development of recommendations for the development of biomonitoring methods for hydro-ecosystems. carried out.

Targeted environmental assessment of the water quality of the Pripiat and Turia Rivers is Key words: ammonia, nitrates, toxicity, water quality, eutrophication, category.

Надійшла 15.05.2019. 